\title{
IMPLEMENTASI PROGRAM KOMPREHENSIF BIMBINGAN DAN KONSELING DALAM PENGEMBANGAN POTENSI SISWA
}

\author{
Sri Damayanti \\ sridamayanti1683@gmail.com \\ (Fakultas Agama Islam, Universitas Muhammadiyah Tangerang)
}

\begin{abstract}
Abstrak:
Pada dasarnya siswa yang memiliki masalah dalam pengembangan potensi membutuhkan penanganan oleh guru bimbingan dan konseling. Sebagai bidang yang memiliki fokus dalam pengentasan masalah yang dialami siswa, tentunya bimbingan dan konseling memiliki media atau layanan konseling yang terdapat dalam peraturan menteri pendidikan yaitu sebagai upaya memaksimalkan dalam memberikan layanan bimbingan dan konseling dalam menangani masalah yang dihadapi siswa. Penelitian ini bertujuan untuk mengetahui bagaimana pelaksanaan program komprehensif bimbingan dan konseling dalam pengembangan potensi siswa di MTs Avicenna Sunan Bonang. Penelitian ini bersifat deskriptif kualitatif dengan mengumpulkan data-data mengenai layanan bimbingan dan konseling yang dilaksanakan oleh guru bimbingan dan konseling dalam melakukan pengembangan potensi siswa.
\end{abstract}

\section{Kata Kunci: Implementasi, Bimbingan Konseling, Pengembangan Potensi.}

\section{Abstract:}

This type research was aims to determine the implementation of a comprehensive program of guidance and conseling in developing the potential of students at MTs Avicenna Sunan Bonang. This type of research is a qualitative descriptive study by collecting data about guidance and conseling services carried out by conseling guidance teachers in developing student potential. he result of this study indicates that study indicate that the implementation of a comprehensive program of guidance and conseling is appropriate in developing the potential of students at MTs Avicenna Sunan Bonang.

\section{Keywords: Implementation, Counseling Guidance, Key Development}

\section{A. Pendahuluan}

Manusia pada hakikatnya diciptakan dalam keadaan yang terbaik, termulia, dan sempurna jika dibandingkan dengan makhluk hidup yang lainnya. Sejak dilahirkan ke dunia Allah SWT sudah memberi berbagai potensi di dalam dirinya untuk dikembangkan secara seimbang. Namun realitas membuktikan bahwa banyak manusia yang ceroboh, hanya mengembangkan dan meningkatkan kualitas potensi tertentu dan menyalahgunakan akalnya sehingga bertindak sesuka hati. Sehingga dalam proses perkembangannya sering sekali menimbulkan konflik dengan lingkungannya. Tidak semua manusia mampu untuk mengatasi kesulitannya sendiri. Pendidikan merupakan salah satu cara dan upaya untuk meningkatkan serta menciptakan manusia yang berkualitas, baik berkualitas pada kecerdasan ataupun karakter. Dengan adanya lembaga pendidikan atau yang biasa disebut sekolah, menjadi bukti bahwa pendidikan harus berproses disuatu tempat dengan segala hal yang mendukung dan menunjang tercapainya tujuan pendidikan. 
Menurut Undang-Undang Sistem Pendidikan Nasional Nomor 20 Tahun 2003 yang berbunyi "Pendidikan nasional berfungsi mengembangkan kemampuan dan membentuk watak serta peradaban bangsa yang bermartabat dalam rangka mencerdaskan kehidupan bangsa. ${ }^{1}$.Pendidikan menjadi hal penting di masyarakat, mulai dari pendidikan di taman kanak-kanak sampai dengan sekolah menengah, seorang anak selalu membutuhkan bimbingan dari orang-orang sekitarnya. Terutama pada tingkat pendidikan di sekolah menengah pertama yang memasuki masa-masa remaja yaitu masa peralihan dari anak-anak menuju dewasa, sebuah periode dalam kehidupan manusia yang batasan usia maupun peranannya sering sekali tidak terlalu jelas atau masa labil. Remaja masih sering mengalami perubahan dan mengalami perkembangan yang cepat baik dari sisi emosi, fisik, minat, dan perilaku. Perubahan yang terjadi akan membawa pengaruh yang besar pada situasi kejiwaannya. Pada masa inilah seorang anak akan mencari jati dirinya dengan melakukan berbagai hal hingga menimbulkan masalah. Contohnya perilaku bolos sekolah, tidak peduli dengan kebersihan lingkungan, tawuran antar pelajar, dan bingung mengembangkan potensinya. Oleh sebab itu pada masamasa remaja masih sangat dibutuhkan bimbingan dan peran aktif dari orang tua, guru, dan masyarakat. Seorang anak/siswa selalu menghabiskan waktunya di rumah dan di sekolah. Artinya selain orang tuanya, para guru juga berperan sebagai pembimbing. Melakukan bimbingan di sekolah merupakan upaya dan bagian dari proses pendidikan guna membantu pertumbuhan siswa dalam menentukan dan mengarahkan kepada kehidupan yang lebih baik. Namun bimbingan saja tidak cukup, diperlukan juga konseling. Bimbingan dan konseling saling berkaitan satu sama lain sehingga tidak dapat dipisahkan. Kebutuhan bimbingan dan konseling harusnya tidak terbatas pada siswa yang bermasalah saja, tetapi siswa yang tidak bermasalah pun memerlukannya karena manusia tidak pernah lepas dari masalah. Bimbingan dan konseling di sekolah merupakan kegiatan untuk membantu peserta didik menemukan dirinya, lingkungannya dan merencanakan masa depan. Sehingga diharapkan ia bisa mencapai kesuksesan dibidang akademis, persiapan karir, dan dalam hubungan sosial kemasyarakatan.

Implementasi program komprehensif bimbingan dan konseling merupakan paradigma baru dalam perkembangan bimbingan dan konseling. Program tersebut lebih berorientasi pada upaya pencegahan dan implementasi programnya telah terbukti efektif. Implementasi program komprehensif merupakan suatu upaya dalam meningkatkan efektifitas layanan bimbingan dan konseling di sekolah. Bimbingan dan konseling ini merupakan penyempurna dari pola 17 yang telah ditetapkan di sekolah. Meskipun program ini adalah penyempurna dari program yang telah ada namun dalam pelaksanaan di lapangan masih banyak pembenahan diberbagai bidang. ${ }^{1}$ Kerangka kerja layanan bimbingan dan konseling komprehensif dikembangkan dalam suatu program bimbingan dan konseling yang dijabarkan dalam empat kegiatan utama yaitu: layanan dasar bimbingan, layanan responsif, layanan perencanaan individual dan dukungan sistem. ${ }^{2}$ Pada prinsipnya bimbingan adalah proses pemberian bantuan yang diberikan kepada seorang

\footnotetext{
${ }^{1}$ Sumaryanto, “Implementasi Program Bimbingan Dan konseling Komprehensif", (Tesis S2 Fakultas Tarbiyah Institut Agama Islam (IAI) Ngawi, h.2

${ }^{2}$ Ardimen, Bimbingan dan Konseling Komprehensif Berbasis Karakter Cerdas, Vol.12, No.2, Agustus 2017, h. 491
} 
atau beberapa orang individu dalam hal memahami diri sendiri, menghubungkan pemahaman tentang dirinya sendiri dengan lingkungan, memilih dan menentukan, dan menyusun rencana sesuai dengan konsep dirinya dan tuntunan lingkungan berdasarkan norma-norma yang berlaku. Adapun bimbingan dijalankan secara group atau kelompok.

Konseling pada prinsipnya dijalankan secara individual, yaitu antara konselor dan klien secara face to face (tatap muka). Konseling pada hakikatnya adalah usaha membantu klien untuk mengatasi permasalahan psikologis yang dialaminya, yaitu membantu mencari alternatif jalan keluar yang tepat sehingga klien dengan secara sadar dapat mengambil keputusan sendiri secara tepat. ${ }^{3}$ Konselor membantu klien untuk mencari cara dalam perubahan itu, namun yang melakukan perubahan adalah klien sendiri dengan penuh kesadaran dan ketulusan. Konselor hanya memberikan bantuan untuk menemukan cara mengatasi masalah tersebut.

Bimbingan dan konseling adalah suatu upaya untuk memberikan pertolongan pada individu yang membutuhkan. Bimbingan merupakan sebuah rancangan khusus sesuai dengan pendidikan tertentu berdasarkan kurikulum sekolah. Sedangkan konseling merupakan bagian dari segala program bimbingan di sekolah. ${ }^{4}$ Dari penjelasan bimbingan dan konseling di atas dapat disimpulkan bahwa bimbingan dan konseling adalah suatu proses pemberian bantuan kepada individu secara berkelanjutan dan sistematis, yang dilakukan oleh seorang ahli yang telah mendapat latihan khusus untuk itu, dengan

${ }^{3}$ Abdul Hayat, Bimbingan Konseling Qur'ani, (Yogyakarta; Pustaka Pesantren, 2017), h. 5

${ }^{4}$ Safwan Amin, Pengantar Bimbingan dan Konseling, (Banda Aceh; Pena, 2014), h.6 tujuan agar individu dapat memahami dirinya, lingkungannya, serta dapat mengarahkan diri dan menyesuaikan diri dengan lingkungan untuk mengembangkan potensi dirinya secara maksimal untuk kesejahteraan dirinya dan kesejahteraan masyarakat.

Pengembangan potensi siswa merupakan proses yang disengaja dan sistematis dalam membiasakan atau mengkondisikan siswa agar memiliki kecakapan dan keterampilan hidup. Kecakapan dan keterampilan yang dimaksud berarti luas, baik kecakapan personal (personal skill) yang mencakup kecakapan mengenali diri sendiri (self awareness) dan kecakapan berpikir rasional (thinking skill), kecakapan akademik (academic skill), kecakapan sosial (social skill), maupun kecakapan vokasional (vocational skill). ${ }^{5}$

Tahapan-tahapan perkembangan yang lebih perlu dipahami sebagai bahan pertimbangan pokok dalam penyelenggaraan proses mengajar belajar adalah tahapan-tahapan yang berhubungan dengan perkembangan ranah cipta para siswa dalam menjalani proses mengajarbelajar dan pembelajaran materi tertentu. ${ }^{6}$ Itulah sebabnya mengapa suatu upaya pendidikan tidak dapat dan tidak boleh dikemukakan dalam bentuk aturan yang tetap untuk dijalankan. Yang penting bukan aturan melainkan kepribadian dan kreatifitas guru sendiri. Pengembangan potensi siswa juga merupakan keseluruhan kemampuan yang terpendam yang ada dalam diri siswa, yang memungkinkan dapat berkembang dan diwujudkan dalam

\footnotetext{
${ }^{5}$ Mulyono, Peningkatan Keterampilan Mengembangkan Potensi Peserta Didik Melalui Pembinaan Bagi Guru Kelas SD Negeri 2 JONO Kec.Tawangharjo Kab. Grobogan Pada Semester I Tahun Pelajaran 2016/2017, Jurnal Pendidikan Dasar, Volume 6, Nomor 2, h. 83

${ }^{6}$ Muhibbin Syah, Psikologi Pendidikan, (Bandung;Remaja Rosdakarya,2016), h. 19
} 
kenyataan. Pada dasarnya setiap siswa mempunyai potensi dasar seperti potensi spiritual, kecerdasan dan fisik yang diberikan oleh Allah SWT untuk dikembangkan dan diaktualisasikan dalam kehidupan. Oleh karena itu, dalam pelaksanaan pendidikan perlu memperhatikan potensi setiap siswa. Penyusunan program sekolah juga perlu untuk diarahkan agar dapat memfasilitasi kebutuhan siswa yang sesuai potensinya. Sehingga setiap siswa mampu mengoptimalkan segala potensi yang dimiliki dan tumbuh menjadi pribadi yang mantap dan mandiri. Sebagaimana tujuan pendidikan nasional yakni mengembangkan segala potensi siswa agar menjadi pribadi yang beriman, bertakwa, berakhlak mulia, memiliki ilmu pengetahuan dan keterampilan, sehat jasmani dan rohani, serta bertanggung jawab. ${ }^{7}$

Menurut peneliti pengembangan potensi siswa yang telah diuraikan di atas adalah kemampuan secara keseluruhan yang dimiliki oleh setiap siswa yang dapat dikembangan melalui berbagai cara. Oleh karena itu tidak semua siswa memiliki kondisi fisik dan psikomotorik yang baik. Adapun potensi intelektual mencakup kecerdasan atau prestasi, kecerdasan umum, kemampuan khusus (bakat) dan kreatifitas, siswa dapat mencari tahu dan memahami kemampuan yang ia miliki.

Berdasarkan hasil observasi di lapangan, terdapat beberapa siswa Mts Avicenna Sunan Bonang yang mengalami masalah dalam proses belajar mengajar mengenai perihal bakat, sikap, dan emosi. Sehingga terbentuknya program implementasi program komprehensif yang sangat membantu dalam upaya meningkatkan efektifitas layanan

${ }^{7}$ Undang-Undang No.22 Tahun 2003 Tentang Sistem Pendidikan Nasional bimbingan dan konseling di sekolah. Bimbingan dan konseling merupakan bagian integral dalam setiap menangani kasus siswa. Tujuan yang hendak dicapai dalam penelitian ini adalah untuk mengetahui hasil akhir yang memuaskan bagi peneliti dan pihak sekolah dalam bimbingan dan konseling secara total dengan menerapkan program komprehensif.

Di MTs Avicenna Sunan Bonang terdapat beberapa siswa yang memiliki masalah dalam pengembangan potensi secara akademiknya meliputi bakat, berfikir, emosi dan sikap. Maka dari itu dibentuklah implementasi program komprehensif bimbingan dan konseling sebagai integral ataupun pelaksanaan rencana dari sistem pendidikan di sekolah, memiliki peran penting berkaitan dengan pemenuhan fungsi dan tujuan pendidikan serta peningkatan mutu pendidikan di sekolah. Maka dari itu peneliti ingin melakukan penelitian mengenai "Implementasi Program Komprehensif Bimbingan dan Konseling dalam Pengembangan Potensi Siswa di MTs Avicenna Sunan Bonang".

\section{B.Kajian Pustaka}

1. Pengertian Bimbingan dan Konseling Bimbingan dan konseling berasal dari dua kata, yaitu bimbingan dan konseling. Bimbingan merupakan terjemahan dari guidance yang di dalamnya terkandung beberapa makna. Guidance berasal dari kata guide yang mempunyai arti to direct, pilot, manager, or steer, artinya: menunjukkan, mengarahkan, menentukan, mengatur, atau mengemudikan. ${ }^{8} \quad$ Munculnya layanan bimbingan dan konseling dalam berbagai setting kehidupan merupakan respon terhadap pentingnya memfasilitasi

\footnotetext{
${ }^{8}$ Anas Salahudin, Bimbingan dan Konseling, (Bandung; Pustaka Setia, 2016), h.14
} 
perkembangan konseling secara optimal. Memfasilitasi yang dimaksud adalah proses memberi berbagai kemudahan melalui pemahaman diri dan lingkungan yang tepat, pengarahan, dan pengembangan diri sesuai dengan potensi yang dimiliki. Potensi yang dimaksud adalah talent power, yakni kemampuan yang belum tampak, belum terlihat, belum menjadi perilaku nyata, atau belum menjadi prestasi. Bimbingan adalah proses membantu individu memahami diri sendiri dan dunia. Di lingkungan sekolah, bimbingan berfokus pada penciptaan lingkungan belajar yang optimal bagi setiap siswa. Bimbingan dilakukan di dalam seluruh kelas yang yang dilakukan secara rutin dalam kurun waktu mingguan.

Secara etimologis, istilah konseling berasal dari bahasa Latin, yaitu "conselium" yang berarti dengan atau "bersama" yang dirangkai dengan "menerima" atau "memahami". Sedangkan dalam bahasa Anglo-Saxon, istilah konseling berasal dari "sellan" yang berarti "menyerahkan". Konseling adalah kegiatan dimana semua fakta dikumpulkan dan semua pengalaman siswa difokuskan pada masalah tertentu untuk diatasi sendiri oleh yang bersangkutan, dimana ia diberi bantuan pribadi dan langsung dalam pemecahan masalah itu. Konselor tidak memecahkan masalah untuk klien. Konseling harus ditujukan pada perkembangan yang progresif dari individu untuk memecahkan masalah-masalahnya sendiri tanpa bantuan. Konseling adalah pribadi yang dapat dilakukan secara tatap muka antara dua orang dalam mana konselor melalui hubungan itu, dengan kemampuan-kemampuan khusus yang dimilikinya, menyediakan situasi belajar. Dalam hal ini klien dibantu untuk memahami diri sendiri, keadaannya sekarang, dan kemungkinan keadaannya masa depan yang dapat ia ciptakan dengan menggunakan potensi yang dimilikinya, demi untuk kesejahteraan pribadi maupun masyarakat. ${ }^{9}$

Bimbingan dan konseling adalah suatu upaya untuk memberikan pertolongan pada individu yang membutuhkan. Bimbingan merupakan sebuah rancangan khusus sesuai dengan pendidikan tertentu berdasarkan kurikulum sekolah. Sedangkan konseling merupakan bagian dari segala program bimbingan di sekolah. ${ }^{10}$ Sesungguhnya bimbingan dan konseling merupakan dua kegiatan kerja yang saling melengkapi. Kesamaan antara bimbingan dan konseling serta perbedaannya, maupun saling melengkapi antara kegiatan bimbingan dan konseling. Pandangan lain lagi ialah bahwa bimbingan dan konseling merupakan kegiatan yang integral, dan keduanya tidak dapat dipisahkan. Oleh karena itu perkataan bimbingan selalu dirangkaikan dengan konseling sebagai kata majemuk. Konseling merupakan salah satu jenis teknik pelayanan bimbingan di antara pelayanan-pelayanan lainnya, dan sering dikatakan sebagai inti dari keseluruhan pelayanan dalam bimbingan.

1) Tujuan Bimbingan dan Konseling

Bimbingan agar siswa mampu merencanakan masa depannya mengandung makna bahwa guru diharapkan mampu membantu siswa mengenal berbagai jenis pekerjaan dan pendidikan yang ada di lingkungan sekitarnya.

1) Tujuan Umum Bimbingan dan Konseling di Sekolah

Tujuan umum pelayanan bimbingan dan konseling pada dasarnya sejalan dengan tujuan pendidikan itu sendiri karena bimbingan dan konseling merupakan bagian integral dari

\footnotetext{
${ }^{9}$ Subarkah Milana Abdillah, Bimbingan Konseling, (Tangerang; UMT Press, 2018), h.83

${ }^{10}$ Safwan Amin, ... ,h. 6
} 
sistem pendidikan. Upaya bimbingan dan konseling memungkinkan siswa mengenal dan menerima diri sendiri serta mengenal dan menerima lingkungannya secara positif dan dinamis serta mampu mengambil keputusan, mengamalkan dan mewujudkan diri sendiri secara efektif dan produktif sesuai dengan peranan yang diinginkannya dimasa depan.

2) Tujuan Khusus Bimbingan dan Konseling di Sekolah

Tujuan khusus bimbingan dan konseling di sekolah, sebagai berikut.

a) Membantu siswa-siswi untuk mengembangkan pemahaman diri sesuai dengan kecakapan, minat, hasil belajar, serta kesempatan yang ada.

b) Membantu siswa-siswi untuk mengembangkan motif-motif dalam belajar, sehingga tercapai kemajuan pengajaran yang berarti.

c) Memberikan dorongan di dalam pengarahan diri, pemecahan masalah, pengambilan keputusan, dan keterlibatan diri dalam proses pendidikan.

d) Membantu siswa-siswi untuk memperoleh kepuasan pribadi dalam penyesuaian diri secara maksimum terhadap masyarakat.

e) Membantu siswa-siswi untuk hidup di dalam kehidupan yang seimbang dalam berbagai aspek fisik, mental dan sosial.

3) Tujuan bimbingan dan konseling bagi guru adalah sebagai berikut:

a) Membantu guru dalam berhubungan dengan siswasiswi.

b) Membantu guru dalam peyesuaian keunikan individual dengan tuntutan umum sekolah dan masyarakat.

c) Membantu guru dengan mengenal pentingnya keterlibatan diri dalam keseluruhan program pendidikan.

d) Membantu keseluruhan program pendidikan untuk menemukan kebutuhan-kebutuhan seluruh siswa.

4) Adapun tujuan bimbingan dan konseling bagi sekolah: ${ }^{11}$

a) Menyusun dan menyesuaikan data tentang siswa yang bermacam- macam.

b) Mengadakan penelitian tentang siswa dari latar belakangnya.

c) Membantu menyelenggarakan kegiatan penataran bagi para guru dan personil lainnya, yang berhubungan dengan kegiatan bimbingan.

d) Mengadakan penelitian lanjutan terhadap siswa-siswi yang telah meninggalkan sekolah.

2) Bidang Bimbingan dan Konseling

Bimbingan dan konseling pada satuan pendidikan mencakup empat bidang layanan, yaitu bidang pribadi, sosial, belajar, dan karir. ${ }^{12}$ Bimbingan dan konseling pada satuan pendidikan mencakup empat bidang layanan, yaitu bidang pribadi, sosial, belajar, dan karir.

3) Layanan Bimbingan dan Konseling ${ }^{13}$

a. Layanan Orientasi

b. Layanan Informasi

c. Layanan Penempatan dan Penyaluran

d. Layanan Penguasaan Konten

${ }^{11}$ Anas Salahudin, ..., h. 23

12 Daryanto, Bimbingan Konseling Panduan Guru Bk dan Guru Umum, (Yogyakarta, Gava Media, 2015), h. 171

${ }^{13}$ ibid, h. 57 
e. Layanan Konseling Perseorangan

f. Layanan Bimbingan Kelompok

g. Layanan Konseling Kelompok

h. Layanan Konsultasi

i. Layanan Mediasi

4) Fungsi Bimbingan dan Konseling

a. Fungsi Pemahaman

b. Fungsi Preventif

c. Fungsi Pengembangan

d. Fungsi Penyembuhan

e. Fungsi Penyaluran

f. Fungsi Adaptasi

g. Fungsi Penyesuaian

h. Fungsi Perbaikan

i. Fungsi Pemeliharaan

5) Asas Bimbingan dan Konseling

Betapa pentingnya asas-asas bimbingan dan konseling ini dikatakan sebagai jiwa dan napas dari seluruh kehidupan layanan bimbingan dan konseling. ${ }^{14}$

a. Asas Kerahasiaan

b. Asas Kesukarelaan

c. Asas Keterbukaan

d. Asas Kegiatan

e. Asas Kemandirian

f. Asas Kekinian

g. Asas Kedinamisan

h. Asas Keterpaduan

i. Asas Kenormatifan

j. Asas Keahlian

k. Asas Alih Tangan Kasus

6) Prinsip Bimbingan dan Konseling

Prinsip bimbingan dan konseling menguraikan pokok-pokok dasar pemikiran yang dijadikan pedoman program pelaksanaan atau aturan main yang harus diikuti dalam pelaksanaan program pelayanan bimbingan dan dapat juga dijadikan sebagai seperangkat landasan praktis yang harus diikuti dalam pelaksanaan program pelayanan bimbingan dan konseling di sekolah. $^{15}$ Pelayanan

\footnotetext{
${ }^{14}$ Anas Salahudin, ..., h. 40

${ }^{15}$ Ibid, h.41
}

bimbingan konseling secara resmi memang ada di sekolah tetapi keberadaannya belum maksimal. Ringkasnya, prinsip-prinsip dalam bimbingan konseling, anatara lain sebagai berikut : ${ }^{16}$

1. Prinsip-prinsip yang berkenaan dengan sasaran layanan:

a)Melayani semua individu tanpa memandang usia, jenis kelamin, suku, agama, dan status sosial

b) Memerhatikan tahapan perkembangan

c)Memerhatikan perbedaan individu dalam layanan.

2. Prinsip-prinsip yang berkenaan dengan permasalahan yang dialami individu:

a)Menyangkut pengaruh kondisi mental maupun fisik individu terhadap penyesuaian pengaruh lingkungan, baik di rumah, sekolah, dan masyarakat

b) Timbulnya masalah pada individu karena adanya kesenjangan sosial, ekonomi, dan budaya.

3. Prinsi-prinsip yang berkenaan dengan program pelayanan bimbingan dan konseling:

a)Bimbingan dan konseling merupakan bagian integral dari pendidikan dan pengembangan individu, sehingga program bimbingan dan konseling diseleraskan dengan program pendidikan dan pengembangan diri siswa

b) Program bimbingan dan konseling harus fleksibel dan disesuaikan dengan kebutuhan siswa maupun lingkungan

c) Program bimbingan dan konseling disusun dengan mempertimbangkan adanya

${ }^{16}$ Ibid, h.47 
tahap perkembangan individu.

4. Prinsip-prinsip yang berkenaan dengan tujuan dan pelaksanaan pelayanan:

a) Diarahkan untuk pengembangan individu yang akhirnya mampu secara mandiri membimbing diri sendiri

b) Proses pelayanan bimbingan dan konseling melibatkan individu yang telah memperoleh hasilpengukuran dan penilaian pelayanan.

c) Pengambilan keputusan yang diambil oleh individu hendaknya atas kemauan diri sendiri.

2. Pengembangan Potensi Siswa

"Perkembangan secara luas menunjuk pada keseluruhan proses perubahan dari potensi dari yang dimiliki individu dan tampil dalam kualitas kemampuan, sifat dan ciri-ciri yang baru. Di dalam istilah perkembangan juga tercakup konsep usia, yang diawali dari saat pembuahan dan berakhir dengan kematian."17 Sedangkan potensi adalah kemampuan yang masih terkandung dalam diri siswa yang diperoleh secara pembawaan. Dengan demikian potensi merupakan modal dan sekaligus batasbatas bagi perkembangan kecakapan nyata atau hasil belajar.

1) Bakat

a) Pengertian bakat

Apa yang diartikan dengan istilah "bakat? Apa perbedaannya dengan "kemampuan" dan dengan "kapasitas"? Apa pula perbedaannya dengan "prestasi"? Bakat umumnya diartikan sebagai kemampuan bawaan yang merupakan potensi yang masih perlu dikembangkan atau dilatih agar dapat terwujud. Kemampuan adalah daya

17 Desmita, Psikologi Perkembangan Peserta Didik, (Bandung, PT Remaja Rosdakarta, 2011), h. 9 untuk melakukan suatu tindakan sebagai hasil dari pembawaan dan latihan. Kemampuan menunjukkan bahwa suatu tindakan dapat dilaksanakan sekarang, sedangkan "bakat" memerlukan latihan dan pendidikan agar suatu tindakan dapat dilakukan pada masa yang akan datang. Kapasitas terkadang digunakan sebagai sinonim untuk "kemampuan", dan diartikan sebagai kemampuan yang dapat dikembangkan sepenuhnya pada masa mendatang apabila kondisi latihan dikemukakan secara optimal. Dalam praktik, kapasitas seseorang jarang tercapai.

b) Jenis-jenis bakat

Jenis bakat atau kemampuan menurut fungsi atau aspek-aspek yang terlihat dan menurut prestasinya. Berdasarkan fungsi atau aspek jiwa raga yang terlihat dalam berbagai macam prestasi, bakat dapat dapat dibedakan sebagai berikut.

1. Bakat yang lebih berdasarkan psikofisik. Bakat jenis ini adalah kemampuan yang berakar pada jasmaniah sebagai dasar dan fundamental bakat.

2. Bakat kejiwaan yang bersifat umum. Jenis bakat ini adalah kemampuan ingatan dan khayal atau imajinasi dan inteligensi. ${ }^{18}$

3. Bakat-bakat kejiwaan yang khas dan majemuk. Bakat-bakat yang khas atau bakat dalam pengertian sempit adalah belajar yang sejak awal sudah ada dan terarah pada suatu lapangan yang terbatas.

4. Bakat yang lebih berdasarkan pada alam perasaan dan kemauan bakat ini berhubungan erat dengan watak, seperti kemampuan untuk mengadakan kontak sosial, kemampuan mengasihi, kemampuan merasakan atau

${ }^{18}$ Alex Sobur, Psikologi Umum, (Lingkar Selatan;Pustaka Setia,2016), h. 166 
menghayati perasaan orang lain.

c) Berpikir dan Bernalar

1. Pengertian berfikir dan bernalar. Berpikir adalah suatu kegiatan mental yang melibatkan kerja otak. Akan tetapi, pikiran manusia, walaupun tidak dapat dipisahkan dari aktivitas kerja otak, lebih dari sekedar kerja organ tubuh yang disebut otak. Kegiatan berpikir juga melibatkan seluruh pribadi manusia serta perasaan dan kehendak manusia. $^{36}$ Berpikir adalah kelangsungan tanggapan-tanggapan di mana subjek yang berpikir pasif. Berpikir itu adalah berbicara dalam hati. Sehubungan dengan ini pendapat yang mengatakan bahwa berpikir adalah aktivitas ideasional. Bahwa berpikir itu adalah aktivitas, jadi subjek yang berpikir aktif, Bahwa aktivitas itu sifatnya ideasional, jadi bukan sensoris dan bukan motoris, walaupun dapat disertai oleh kedua hal itu, berpikir itu mempergunakan abstraksiabstraksi atau "ideal". Pada hakikatnya, berpikir merupakan ciri utama bagi manusia untuk membedakan antara manusia dan makhluk lain. Dengan dasar berpikir ini, manusia dapat mengubah keadaan alam sejauh akal dapat memikirkannya. Berpikir disebut juga sebagai proses bekerjanya akal; manusia dapat berpikir karena manusia berakal.

2. Macam-macam berfikir. Adapun berpikir realistis atau sering disebut reasoning (nalar) adalah berpikir dalam rangka menyesuaikan diri dengan dunia nyata. Ada tiga macam berpikir realistis, yaitu deduktif, induktif dan evaluatif. ${ }^{19}$

d) Emosi

${ }^{19}$ Ibid, h. 186
Emosi pada umumnya berlangsung dalam waktu yang relatif singkat, sehingga emosi berbeda dengan mood. Mood atau suasana hati umumnya berlangsung dalam waktu yang relatif lebih lama daripada emosi, tetapi intensitasnya kurang apabila dibandingkan dengan emosi. Apabila seseorang mengalami marah (emosi), maka kemarahan ini tidak segera hilang begitu saja, tetapi masih terus berlangsung dalam jiwa seseorang (ini yang dimaksud dengan mood) yang akan berperan dalam diri orang yang bersangkutan. 20 Berbagai emosi dapat muncul dalam diri seperti sedih, gembira, kecewa, benci, cinta, marah. Oleh karena itu, sering dikemukakan bahwa emosi merupakan keadaan yang ditimbulkan oleh situasi tertentu (khusus), dan emosi cenderung terjadi dalam kaitannya dengan perilaku yang mengarah (approach) atau menyingkiri (avoidance) terhadap sesuatu, dan perilaku tersebut pada umumnya disertai adanya ekspresi kejasmanian, sehingga orang lain dapat mengetahui bahwa seseorang sedang mengalami emosi.

e) Sikap

1. Pengertian Sikap. Sikap merupakan salah satu pokok bahasan yang penting dalam psikologi, khususnya psikologi sosial, para ahli tidak selalu sepakat mengenai pengertian atau definisinya. ${ }^{21}$

2. Komponen Sikap. Berdasarkan definisi tersebut, suatu sikap mengandung tiga komponen, yaitu: (1) komponen kognitif

${ }^{20}$ Yudrik Jahja, Psikologi Perkembangan, (Bandung, Prenada Medis, 2017), h.59

${ }^{21}$ Alex Sobur, ..., h.307 
(keyakinan); (2) komponen afektif (emosi/perasaan); (3) komponen perilaku (tindakan).

\section{Hasil Penelitian dan Pembahasan}

1. Bagaimana program komprehensif bimbingan dan konseling di sekolah MTs Avicenna Sunan Bonang. Kegiatan bimbingan dan konseling di sekolah sangat memiliki peranan penting demi perkembangan optimal bagi siswa. Bimbingan konseling di sekolah bertindak sebagai pengampu layanan bimbingan, salah satunya memotivasi siswa dan memberikan bimbingan yang bermanfaat bagi siswa. Berdasarkan hasil wawancara dengan guru bimbingan konseling mengenai proses pelaksanaannya di sekolah MTs Avicenna Sunan Bonang, yaitu: tujuan dari kegiatan bimbingan dan konseling ini adalah suatu upaya dalam membentuk perkembangan siswa baik dalam kepribadian maupun lingkungan. Dan membantu siswa untuk mengembangkan pemahaman diri sesuai dengan minat dan bakat yang mereka miliki. Agar siswa dapat mempersiapkan dan merencanakan masa depannya dengan baik. $^{22}$ Pada hakikatnya bimbingan konseling adalah memandirikan siswa atau suatu proses usaha yang diberikan guru bimbingan konseling untuk membantu siswa agar dapat mengembangkan potensi atau mengatasi masalah. Selanjutnya dipertegas melalui wawancara dengan kepala sekolah dan guru bimbingan konseling, sebagai berikut: Bidang layanan dalam bimbingan dan konseling pastinya sangat mendukung dalam pelaksanaannya karna mencakup bidang pribadi, bidang sosial, bidang belajar,

\footnotetext{
${ }^{22}$ Dewi Sukmawati, Guru Bidang (Bimbingan Konseling), Wawancara, 26 Oktober 2020 .
}

dan bidang karir. $^{23}$ Keempat bidang layanan itu semuanya saya terapkan, tetapi disesuaikan dengan masalah yang mereka hadapi dan yang saya sering hadapi adalah siswa kelas 8 yang difokuskan menggunakan bidang layanan pribadi dan sosial karena diumur mereka yang beranjak 15 tahun sangat dibutuhkan pengenalan diri, karakter maupun sifat sedangkan dalam sosialnya agar mereka lebih memahami kehidupan bersosialisasi dengan masyarakat. $^{24}$ Di dalam kegiatan bimbingan dan konseling juga terdapat fungsi- fungsi ini juga merupakan dari salah satu bagian penting agar tercapainya pelaksanaan bimbingan konseling. Berdasarkan hasil wawancara dengan guru bimbingan konseling yaitu : Sebelum saya menerapkan fungsi bimbingan dan konseling terlebih dahulu saya lihat masalah apa yang siswa itu sedang hadapi. Setelah saya mengetahui masalahnya baru saya gunakan beberapa fungsi tersebut yang sering saya terapkan adalah fungsi pemahaman supaya siswa itu dapat memilih terhadap dirinya maupun lingkungannya. Fungsi adaptasi, fungsi penyesuian dan fungsi perbaikan. Bagian yang terpenting dalam bimbingan dan konseling adalah asasasas karena merupakan hukum dasar. Berdasarkan hasil wawancara dengan guru bimbingan konseling dan kepala sekolah, sebagai berikut : Asas yang mencakup ruang lingkup bimbingan dan konseling itu pasti sudah pasti gunakan oleh guru bimbingan konseling dalam pelaksanaannya. ${ }^{25}$ Tentu saja saya gunakan dalam bimbingan dan

\footnotetext{
${ }^{23}$ Ibid,.

${ }^{24}$ Bpk. Abdul Muchith (Kepala sekolah MTs Avicenna Sunan Bonang), Wawancara, 26 Oktober

25 Ibid,
} 2020 
konseling karena asas-asas ini sangat penting, terutama dalam asas kerahasiaan karena dalam asas itu saya selaku guru bimbingan konseling mempunyai tanggung jawab besar dalam data maupun keterangan siswa yang telah didapatkan dari proses tatap muka. $^{26}$ Bagian selanjutnya adalah prinsip dalam bimbingan konseling, berdasarkan hasil wawancara dengan guru bimbingan dan konseling, yaitu: Hampir semua prinsip saya terapkan kepada siswa, karena prinsip yang berkenaan dengan sasaran layanan yakni dengan melayani semua siswa tanpa memandang jenis kelamin, agama maupun status sosialnya. Yang ada keterkaitannya dengan kondisi fisik maupun mental siswa. Intinya dari semua prinsip bimbingan dan konseling yang saya terapkan adalah untuk pengembangan individu sehingga mampu mandiri dan jika dalam mengambil keputusan telah difikirkan secara mendalam. ${ }^{27}$ Berdasarkan informasi wawancara dan observasi tersebut dapat diambil kesimpulan yaitu, bimbingan dan konseling memang sangat dibutuhkan dalam menangani berbagai macam karakter, dan sifat siswa. Agar siswa dapat memahami dan bisa mempersiapkan cita cita dan segala suatu hal nya dengan lebih baik.

2. Bagaimana pengembangan potensi siswa di sekolah MTs Avicenna Sunan Bonang. Pendidikan yang berlaku di Indonesia, pada umumnya diselenggarakan dalam bentuk klasikal. Oleh karena itu yang harus mendapat perhatian di dalam penyelenggaraan pendidikan adalah sifat-sifat dan kebutuhan umum remaja, seperti pengakuan akan kemampuannya, untuk mendapatkan kepercayaan dan

\footnotetext{
${ }^{26}$ Dewi Sukmawati,...

${ }^{27}$ Dewi Sukmawati,...
}

kebebasan beberapa penyelenggaraan pendidikan sehubungan dengan bakat dan minat yang dikaitkan dengan cita cita.

Berdasarkan hasil wawancara dengan siswa, sebagai berikut: Saya senang setelah mendapat arahan seperti ini karena sebelumnya saya masih bingung dengan bakat yang saya miliki. Setelah saya mendapat arahan dari guru bimbingan konseling saya menjadi tahu dan lebih paham lagi mengenai bakat dan macam macam bakat. ${ }^{28}$ Potensi diri yang dimiliki setiap siswa berbeda maka seharusnya dapat disalurkan dengan baik oleh sekolah sebagai lembaga pendidikan, anak terkadang merasa bosan dengan proses belajar mengajar, kegiatan ekstrakulikuler dapat menjadi salah satu jalan untuk menyalurkan bakat yang dimiliki setiap siswa. Dan guru pun dapat mengarahkan siswa dalam menyalurkan hobi yang sesuai dengan bakatnya karena itu sangat berpengaruh besar pada pembentukan prestasi yang hendak diraih. Berdasarkan hasil wawancara dengan siswa, yaitu: Saya merasa senang karena mendapat arahan mengenai bimbingan karir karena dapat mengarahkan saya untuk menentukan jenis pekerjaan sesuai dengan kemampuan yang saya miliki. ${ }^{29}$

3. Bagaimana implementasi program komprehensif bimbingan dan konseling dalam pengembangan potensi siswa di sekolah MTs Avicenna Sunan Bonang. Berdasarkan hasil wawancara dengan guru bimbingan dan konseling dan kepala sekolah, yaitu: Semoga semakin baik dan ada peningkatan dalam pelaksanaan bimbingan dan konseling untuk kedepannya. Selain itu agar guru

\footnotetext{
${ }^{28}$ Ardiansyah, Peserta Didik, Wawancara.

${ }^{29}$ Muhammad Irfan, Peserta Didik,
} 
bimbingan dan konseling lebih siap siaga dan tanggap dalam menangani kasus kasus baru yang mungkin akan lebih sulit. $^{30}$ Teruatama untuk siswa agar mereka dapat memahami segala sesuatu hal yang telah diberikan oleh guru bimbingan dan konseling lebih mudah dimengerti dan dapat menerima pemahaman mengenai hal pengembangan potensi siswa agar siswa dapat merencanakan atau menyusun masa depan dan cita citanya dan supaya bisa membentuk karakter kepribadian dan lingkungan yang lebih baik. ${ }^{31}$

\section{A. Kesimpulan}

Berdasarkan penelitian mengenai implementasi layanan bimbingan dan konseling dalam pengembangan potensi siswa di MTs Avicenna Sunan Bonang, maka dapat disimpulkan yaitu bahwa proses pelaksanaaan program komprehensif bimbingan dan konseling sudah tepat, karena sesuai dengan aspek bimbingan dan konseling dalam pengembangan potensi, seperti berjalannya bidang layanan bimbingan pribadi, sosial, belajar dan karir, fungsi dan prinsip dasar bimbingan konseling, meskipun belum sepenuhnya terlaksana dengan baik. Hal ini dapat dilihat dari perkembangan siswa di MTs Avicenna Sunan Bonang di mana siswa mendapat arahan mengenai bimbingan karir karena dapat mengarahkannya untuk menentukan jenis pekerjaan sesuai dengan kemampuan yang dimiliki.

\section{DAFTAR PUSTAKA}

Abdillah Milana Subarkah, Bimbingan Konseling, Tangerang, UMT Press, 2018.

\footnotetext{
${ }^{30}$ Bpk. Abdul Muchith (Kepala sekolah MTs Avicenna Sunan Bonang), Wawancara, 26 Oktober 2020

${ }^{31}$ Dewi Sukmawati,.
}

Abdul Hayat, Bimbingan Konseling Qur'ani, Yogyakarta, Pustaka Pesantren, 2017.

Alex Sobur, Psikologi Umum, Lingkar Selatan, Pustaka Setia, 2016.

Ardimen, Bimbingan dan Konseling Komprehensif Berbasis Karakter Cerdas, Vol.12, No.2, Agustus 2017.

Daryanto, Bimbingan Konseling Panduan Guru Bk dan Guru Umum, Yogyakarta, Gava Media, 2015.

Desmita, Psikologi Perkembangan Peserta Didik, Bandung, PT Remaja Rosdakarta, 2011.

Djamarah Bahri Syaiful, Strategi Belajar Mengajar, Jakarta, PT Asdi Mahasatya,2010.

Mudyaharjo Redja, Pengantar Pendidikan, Jakarta, PT. Raja Grafindo, 2001.

Muhibbin Syah, Psikologi Pendidikan, Bandung, Remaja Rosdakarya, 2016.

Mulyono, Peningkatan Keterampilan Mengembangkan Potensi Peserta

Didik Melalui Pembinaan Bagi Guru Kelas SD Negeri 2 Jono Kec.Tawangharjo Kab. Grobogan Pada Semester I Tahun Pelajaran 2016/2017, Jurnal Pendidikan Dasar, Volume 6, Nomor 2.

Safwan Amin, Pengantar Bimbingan dan Konseling, Banda Aceh, Pena, 2014.

Salahudin Anas, Bimbingan dan Konseling, Bandung, Pustaka Setia, 2016.

Undang-undang Republik Indonesia No. 20 tahun 2003, Tentang Sistem Pendidikan Nasional, Bandung, Fokus Media, 2006.

Wawancara Dewi Sukmawati, Guru Bidang (Bimbingan Konseling), 26 Oktober 2020.

Wawancara Abdul Muchith (Kepala sekolah MTs Avicenna Sunan Bonang), 26 Oktober 2020

Wawancara Ardiansyah, Peserta Didik 
Wawancara Muhammad Irfan, Peserta Didik

Yudrik Jahja, Psikologi Perkembangan,

Bandung, Prenada Medis, 2017).

Robbins, P. Stephen. Organizational Behavior; Elevent Edition. Pearson Education.Inc., Upper Saddle, River. New Jersey. 2005

Schein, E. H. Organizational Culture and Leadership, San Fransisco: JosseyBass, 1985.

Soetopo, Hendyat. Perilaku Organisasi; Teori dan Praktek di Bidang Pendidikan. Bandung. Remaja Rosdakarya. 2010

Soetopo, Hendyat .Perilaku Organisasi; Teori dan Praktek di Bidang Pendidikan. Bandung. Remaja Rosdakarya, 2010
Rivai, Veithzal, Kepemimpinan dan Perilaku Organisasi, Jakarta: Rajawali Pers, 2003

Tim Dosen, AP. UPI. Manajemen Pendidikan. Bandung. Alfabeta, 2009

Wayne K.Hoy dan Cecil G.Miskel, Administrasi dan Pendidikan (Teori, Riset, dan Praktik) diterjemahkan dari "Educational Administrational" Pustaka Pelajar Yogyakarta, 2013 
Implementasi Program Komprehensif Bimbingan Dan Konseling Dalam Pengembangan Potensi

Siswa 